\title{
P04.52. Alternative and complementary health practices among college students: implications for health promotion in higher education
}

\author{
A Burke \\ From International Research Congress on Integrative Medicine and Health 2012 \\ Portland, Oregon, USA. 15-18 May 2012
}

\section{Purpose}

Alternative and Complementary Health Practices (ACHP) may provide new opportunities for encouraging positive health behaviors among college students, such as reducing excessive alcohol use, a persistent campus challenge. To explore this issue a survey was conducted to examine the relationship between ACHP use and health behaviors.

\section{Methods}

The CORE, a national college drug and alcohol survey, was completed by a convenience sample of 2,312 respondents at a state university. The 39-item survey was augmented with 18 questions, including items on ACHP use and identification with postmodern social values.

\section{Results}

For comparison respondents were dichotomized into ACHP users and non-users - based on their response to a frequency of use survey item. This produced a group of 531 (31.3\%) ACHP-users and 1,164 non-users. ACHP students were significantly more likely to be female $(71.4 \%$ users versus $63.0 \%$ non-users, $\mathrm{p}=.001)$ and older (24.4 versus $23.3, \mathrm{p}=.001$ ). There were no statistically significant differences between the two groups in terms of past 30 day use of alcohol, tobacco, or marijuana, binge drinking, or perceived risks from binge drinking. ACHP students were significantly more likely to report engaging in conventional health practices $(\mathrm{p}=.001)$, and having a higher self-reported health status $(\mathrm{p}=.007)$. They also reported experiencing more mental health symptoms during the school year $(\mathrm{p}=.012)$. Finally, ACHP students were significantly more likely to

San Francisco State University, San Francisco, USA report identification with postmodern social values including interest in the environment $(\mathrm{p}=.001)$ and social justice $(\mathrm{p}=.001)$, and to having a somewhat more liberal political orientation.

\section{Conclusion}

Despite a lack of significant differences in alcohol use and other risk behaviors, there is a foreseeable long-term value in promoting ACHP on college campuses due to its current use by many students (31.3\% reporting use in the past 30 days), its relationships with other conventional preventive health practices, and its association with positive social values.

Published: 12 June 2012

doi:10.1186/1472-6882-12-S1-P322

Cite this article as: Burke: P04.52. Alternative and complementary health practices among college students: implications for health promotion in higher education. BMC Complementary and Alternative Medicine 2012 12(Suppl 1):P322.

Submit your next manuscript to BioMed Central and take full advantage of:

- Convenient online submission

- Thorough peer review

- No space constraints or color figure charges

- Immediate publication on acceptance

- Inclusion in PubMed, CAS, Scopus and Google Scholar

- Research which is freely available for redistribution 